\title{
Dexamethasone enhances phospholipase D activity in M-1 cells
}

\author{
Won-Jin Kim ${ }^{1}$, Min-Jung Lee ${ }^{1}$, \\ Myung-Ae Park', Jin-Sup Jung ${ }^{2}$, \\ David J. Uhlinger ${ }^{3}$ and Jong-Young Kwak ${ }^{1,4}$ \\ ${ }^{1}$ Department of Biochemistry, Dong-A University College of \\ Medicine, Pusan 602-103, Korea \\ ${ }^{2}$ Department of Physiology, College of Medicine, \\ Pusan National University, Pusan 602-739, Korea \\ ${ }^{3}$ Department of Drug Discovery, R. W. Johnson Pharmaceutical \\ Research Institute, Raritan, New Jersey 08869, USA \\ ${ }^{4}$ Corresponding author: Tel, +82-51-240-2928; \\ Fax, +82-51-241-6940; E-mail, jykwak@mail.donga.ac.kr
}

Accepted 14 August 2000

Abbreviations: ARF, ADP-ribosylation factor; GTP $\gamma$ S, guanosine 5'O-(3-thiotriphosphate); $\mathrm{PA}$, phosphatidic acid; $\mathrm{PC}$, phosphatidylcholine; PEth, phosphatidylethanol; $\mathrm{PIP}_{2}$, phosphatidylinositol 4,5-bisphosphate; PKC, protein kinase C; PLD, phospholipase D; PMA, phorbol 12-myristate 13-acetate

\begin{abstract}
Phospholipase D (PLD) is an enzyme involved in signal transduction and widely distributed in mammalian cells. The signal transduction pathways and role for phospholipid metabolism during hormonal response in cortical collecting duct remain partly undefined. It has been reported that dexamethasone increases transepithelial transport in $\mathrm{M}-1$ cells that are derived from the mouse cortical collecting duct. We investigated the expression and activity of PLD in $M-1$ cells. Basal PLD activity of $M-1$ cells cultured in the presence of dexamethasone $(5 \mu \mathrm{M})$ was higher than in the absence of dexamethasone. Dexamethasone and ATP activated PLD in M-1 cells but phorbol ester did not stimulate PLD activity. Vasopressin, bradykinin, dibutyryl cyclic AMP, and ionomycin were ineffective in activating PLD of the cells. The PLD2 isotype was detected by immunoprecipitation but PLD1 was not detected in M-1 cells. Addition of GTPYS and ADP-ribosylation factor or phosphatidylinositiol 4,5-bisphosphate to digitonin-permeabilized cells did not augment PLD activity. In intact cells PLD activity was increased by sodium oleate but there was no significant change between dexamethasone treated- and untreated cells by oleate. These results suggest that at least two types of PLD
\end{abstract}

are present in M-1 cells and PLD plays a role in the corticosteroid-mediated response of cortical collecting duct cells.

Keywords: Phospholipase D, dexamethasone, M-1 cell, oleate

\section{Introduction}

Mammalian phospholipase D (PLD) activity is very low and becomes up-regulated transiently when cells are stimulated by a variety of hormones, growth factors, and other extracellular signals (Exton, 1997). PLD hydrolyses phosphatidylcholine (PC), the major component of membrane phospholipid to phosphatidic acid (PA) and choline (Bocckino et al., 1987). PA is used as a messenger for signal transduction and can be further metabolized by PA phosphohydrolase to form diacylglycerol and by phospholipase $A_{2}$ to form lysophosphatidic acid, which have important physiological functions (Cross et al., 1996; Ktistakis et al., 1996; Jones et al., 1999).

Two PLDs (PLD1 and PLD2) have been cloned and characterized (Hammond et al., 1995; Colley et al., 1997b). PLD1 and PLD2 differ with respect to both regulatory and subcellular localization (Colley et al., 1997b). PLD1 localizes to the perinuclear region (endoplasmic reticulum, Golgi apparatus, and late endosomes) but PLD2 localizes primarily to the plasma membrane. PLD1 has a low basal activity that is increased by regulators including protein kinase $C$ (PKC), tyrosine kinase, $\mathrm{Ca}^{2+}$, and low molecular weight GTP-binding proteins such as ADPribosylation factor (ARF) and RhoA (Hammond et al., 1997). In contrast, PLD2 exhibits a high basal activity that can be further increased by addition of phosphatidylinositol 4,5-bisphosphate $\left(\mathrm{PIP}_{2}\right)$ and oleate but not further activated by PKC, ARF, or Rho in vitro (Lopez et al., 1998; Exton, 1999; Kim et al., 1999a). In addition, several groups reported another form of PLD that is activated by detergent including oleate (Chalifour and Kanfer, 1982; Massenburg et al., 1994; Okamura and Yamashita, 1994). Oleate-dependent PLD has been purified from pig lung membranes but it requires further characterization (Okamura and Yamashita, 1994).

M-1 cells have been developed from microdissected cortical collecting duct of a mouse transgenic for the early region of simian virus 40 (Stoos et al., 1991). M1 cells, which preserve functional properties typical for cortical collecting duct principal cells in vivo, reabsorb sodium and secrete potassium through a corticosteroid 
regulated $\mathrm{Na}^{+}$channel (Chalfant et al., 1996). Recent studies have demonstrated that dexamethasone stimulates $\mathrm{Na}^{+}$transport in M-1 cells (Nakhoul et al., 1998). Hormones are able to regulate a variety of ion channels indirectly by cytoplasmic pathways involving second messengers (Breyer and Ando, 1994).

It has been reported that both PLD1 and PLD2 are present in mouse kidney but only PLD2 can be detected in human kidney tissue (Colley et al., 1997a; Meier et al., 1999). Activation of PLD and subsequent production of PA are known to be key early event and regulatory in intracellular vesicle trafficking and exocytosis (Jones et al., 1999; Roth, 1999). In epithelial cells, rapid changes in ion transport involve exocytosis and fusion of intracellular vesicles containing transport protein and ion channels with the plasma membrane (Denker and Nigam, 1998). Vesicle trafficking also plays an important role on water reabsorption and secretion of acid or base in cortical collecting duct (Brown, 1989).

However, it is not known whether these hormonal effects involve metabolism and signaling machinery of phospholipid by PLD. The purpose of the present investigation was to determine PLD activity and the effect of agents modulating ion transport on the activity in $\mathrm{M}-1$ cells.

\section{Materials and Methods}

\section{Materials}

$\left[9,10-{ }^{3} \mathrm{H}(\mathrm{N})\right]$ myristic aicd $(10-60 \mathrm{Ci} / \mathrm{mmol})$ was purchased from Dupont-New England Nuclear (Boston, USA). Dexamethasone, phorbol 12-myristate 13-acetate (PMA), guanosine 5'-gamma-thio-triphosphate (GTP $\gamma$ S), vasopressin, ATP, dibutyryl cyclic AMP (dbcAMP), ionomycin, digitonin, protein A-agarose, culture media and sodium oleate were from Sigma. Silica gel 60 TLC plate was purchased from Merck. Authentic phosphatidylethanol (PEth) was from Avanti polar-Lipids Inc. (Alabaster, USA). Recombinant ARF1 was prepared from Escherichia coli expressing human ARF1 and yeast myristoylCoA: protein $\mathrm{N}$-myristoyltransferase (Lambeth et al., 1995). Anti-PLD1 antibody was a generous gift from Dr. Sung Ho Ryu at Pohang University of Science and Technology (Lee et al., 1997). Polyclonal rabbit anti-sera against PLD2 were produced by immunization with a synthetic peptide encoding the 13 amino acids of mouse PLD2 (DRPFEDFIDRETT). The anti-sera recognized mouse PLD1 and PLD2, respectively.

\section{Cell culture}

M-1 cells were grown in culture dishes in DMEM/Ham's F-12 (1: 1 mixture) containing 10\% fetal bovine serum, $100 \mathrm{U} / \mathrm{ml}$ penicillin, $100 \mu \mathrm{g} / \mathrm{ml}$ streptomycin. In appropriate experiments, dexamethasone was added to a final concentration of $5 \mu \mathrm{M}$.

\section{Measurement of PLD activity}

Assay of PLD activity was based upon the unique ability of this enzyme to stimulate transphosphatidylation in the presence of ethanol to form the corresponding PEth (Kang et al., 1998; Park et al., 1999). M-1 cells were labeled with $\left[{ }^{3} \mathrm{H}\right]$ myristic acid $(1 \mu \mathrm{Ci} / \mathrm{ml})$ for $16 \mathrm{~h}$. The cells were washed twice by phosphate buffered saline (PBS) and resuspended in assay buffer $(20 \mathrm{mM}$ Hepes, $\mathrm{pH}$ 7.4, $137 \mathrm{mM} \mathrm{NaCl}, 2.7 \mathrm{mM} \mathrm{KCl}, 3 \mathrm{mM} \mathrm{MgCl}$, $2 \mathrm{mM}$ $\mathrm{CaCl}_{2}, 2 \mathrm{mM}$ EGTA, and $1 \mathrm{mg} / \mathrm{ml}$ bovine serum albu$\mathrm{min})$. After incubation for $20 \mathrm{~min}$ at $37^{\circ} \mathrm{C}$ in the presence of $1.6 \%$ ethanol, reactions were stopped by addition of $1 \mathrm{ml}$ of $\mathrm{CHCl}_{3} / \mathrm{CH}_{3} \mathrm{OH} /$ concentrated $\mathrm{HCl}$ ( $50: 50: 0.3$, volume/volume), and $0.35 \mathrm{ml}$ of $1 \mathrm{M} \mathrm{HCl} /$ $5 \mathrm{mM}$ EGTA. Lipids were extracted and separated on Silica gel 60 TLC plates in a solvent system consisting of ethyl acetate/trimethyl pentane/acetic $\mathrm{acid} / \mathrm{H}_{2} \mathrm{O}(13: 2$ : $3: 10$, volume/volume). The plates were exposed to iodine vapor and $\left[{ }^{3} \mathrm{H}\right] \mathrm{PE}$ th was identified by comigration with PEth carrier. Radioactive $\left[{ }^{3} \mathrm{H}\right]$ PEth was scraped off the plates and quantitated in a liquid scintillation counter (Beckman LS 5801). The amount of radioactivity in PEth was expressed as percentage of total counts in each lane.

\section{Immunoprecipitation and Western blot of PLD pro- teins}

The cells were lysed in buffer containing $20 \mathrm{mM}$ Tris$\mathrm{HCl}, \mathrm{pH} 7.4,50 \mathrm{mM} \mathrm{NaCl}, 1 \%$ Triton X-100, 1\% deoxycholic acid, $1 \mu \mathrm{g}$ leupeptin, $1 \mu \mathrm{g}$ pepstatin A, $1 \mu \mathrm{g}$ aprotinin, and $1 \mathrm{mM}$ PMSF. The lysates $(10 \mathrm{mg})$ were incubated with $2 \mu \mathrm{g}$ anti-PLD antibody bound to protein A agarose for $1 \mathrm{~h}$ (Lee et al., 1997). The beads were washed with PBS containing 1\% Triton X-100 three times and further washed with the PBS three times. Cell lysates $(100 \mu \mathrm{g})$ and immunoprecipiated beads were subjected to $7.5 \%$ sodium dodecyl sulfate-polyacrylamide gel electrophoresis and then transferred to nitrocellulose membranes. The membranes were blocked for $1 \mathrm{~h}$ at $25^{\circ} \mathrm{C}$ with blocking buffer $(10 \mathrm{mM}$ Tris $\mathrm{HCl}$, $0.15 \mathrm{M} \mathrm{NaCl}, 0.1 \%$ sodium azide and $5 \%$ skim milk) and incubated with a mixture of primary polyclonal antibodies directed against PLD1 and PLD2 $(1: 1000)$ in blocking buffer overnight at $4^{\circ} \mathrm{C}$. Secondary antibody directed against rabbit IgG conjugated to HRP was diluted $1: 10,000$ in blocking buffer and incubated for $1 \mathrm{~h}$. The signal was detected by enhanced chemiluminescence on Hyperfilm-ECL from Amersham International.

\section{Statistical analysis}

Results were expressed as mean values \pm standard deviation of the mean (SD). Student's $t$-test was used to compare the mean PLD activity. A $P$ value $<0.05$ was considered significant. 


\section{Results}

PLD activity was measured in the presence of ethanol, as PLD catalyzes the transphosphatidylation reaction that yields the stable product PEth. Cells were cultured in the presence or absence of $5 \mu \mathrm{M}$ dexamethasone for 4 days. The level of $\left[{ }^{3} \mathrm{H}\right] \mathrm{PE}$ th was measured $15 \mathrm{~min}$ after incubation of the cells with agonist since no further increase of activity was observed even in the prolonged incubations. As shown in Figure 1, mean basal PLD activity was higher in cells that were cultured in the presence of dexamethasone than in untreated cells (1.53 $\pm 0.05 \%$ vs $0.74 \pm 0.1 \%$ ). Phorbol 12 -myristate 13 -acetate (PMA) treatment has been previously shown to activate PLD activity in various cell systems (Exton, 1997). However, no stimulation was observed with 100 nM PMA for up to $1 \mathrm{~h}$ in $\mathrm{M}-1$ cells obtained from both culture conditions (Figure 1). This result shows that activation of PKC is not essential for activation of PLD in M-1 cells. At the same time we found that addition of dexamethasone to cells in culture medium increased transepithelial resistance of M-1 cells (data not shown). We investigated whether dexamethasone directly stimulates the PLD activity of M-1 cells. PLD activity was increased up to $230 \%$ by dexamethasone in control $\mathrm{M}-1$ cells (Figure 2 ). Dose-dependent effect of dexamethasone on PLD activity in both cells was evaluated. Total $\left[{ }^{3} \mathrm{H}\right] \mathrm{PE}$ th formation in control and dexamethasone-treated cells was obtained by incubation of the cells with $0.1 \mu \mathrm{M}$ dexamethasone (Figure 3). When cultured cells in the presence of dexamethasone were treated with same agent, PLD

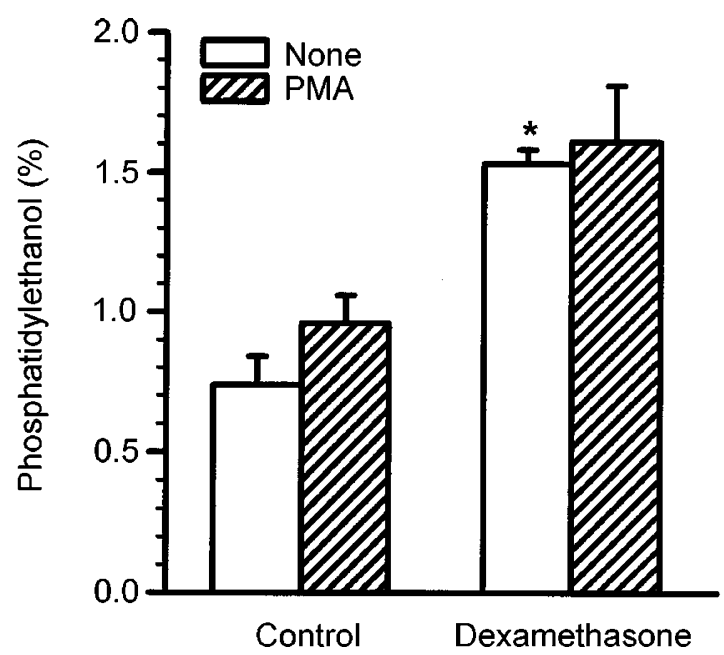

Figure 1. PLD activity of M-1 cells. M-1 cells which had been cultured in the absence (control) or presence of $5 \mu \mathrm{M}$ dexamethasone were radiolabeled with $\left[{ }^{3} \mathrm{H}\right]$ myristic acid. The cells at $1 \times 10^{6} / \mathrm{ml}$ in buffer containing $1.6 \%$ ethanol were incubated with or without $100 \mathrm{nM}$ PMA for $15 \mathrm{~min}$. PEth formation was expressed as percentage of total $\left[{ }^{3} \mathrm{H}\right]$ phospholipid. Data represent mean $\pm S D$ of three independent experiments. Statistical significance was evaluated by Student's t test ( ${ }^{*} p<0.05$ compared to control)

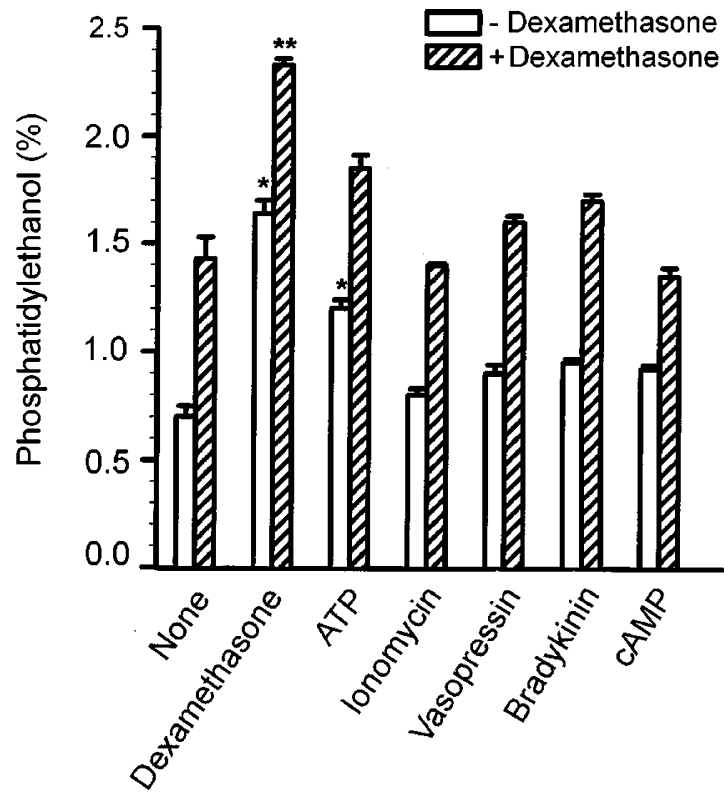

Figure 2. Effects of various agents on PLD activity in M-1 cells. M-1 cells which had been cultured with (+Dexamethasone) or without (-Dexamethasone) $5 \mu \mathrm{M}$ dexamethasone were harvested and radiolabeled as described in "Materials and Methods". The cells were incubated in the absence or presence of $1 \mu \mathrm{M}$ dexamethasone, $10 \mu \mathrm{M}$ ATP, $1 \mu \mathrm{M}$ ionomycin, $1 \mu \mathrm{M}$ vasopressin, $1 \mu \mathrm{M}$ bradykinin, and $0.3 \mathrm{mM}$ dibutyryl cAMP (CAMP) for $15 \mathrm{~min}$. Data represent mean \pm SD of three independent experiments. Statistical significance was evaluated by Student's $t$ test $\left({ }^{\star} P<0.05\right.$; compared to no treatment, ${ }^{\star *} P<0.05$; compared to cells cultured without dexamethasone)

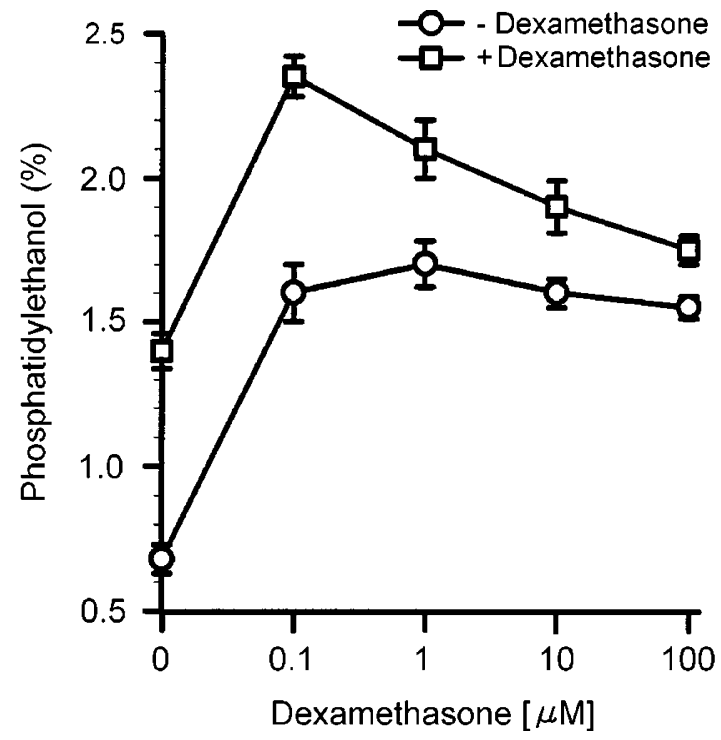

Figure 3. Dose-dependent effects of dexamethasone on PLD activity in M1 cells. M-1 cells which had been cultured with or without $5 \mu \mathrm{M}$ dexamethasone were obtained as in Figure 2. Cells were incubated in the presence of the indicated concentrations of dexamethasone for $15 \mathrm{~min}$. $\left.{ }^{3} \mathrm{H}\right] \mathrm{PE}$ th formation was measured as described in "Materials and Methods". Values are means \pm SD of four determinations. 
activity was further increased (from $1.40 \pm 0.06 \%$ to $2.33 \pm 0.03 \%$ ) and declined thereafter.

In cortical collecting duct, several agonists including vasopressin, bradykinin, ATP, and cAMP can activate transport machinery (Breyer and Ando, 1994). The effect of various agonists upon the activation of PLD was investigated and these results are presented in Figure 2. Stimulation of M-1 cells with ATP induced formation of $\left[{ }^{3} \mathrm{H}\right]$ PEth with maximal activation occurring at $100 \mu \mathrm{M}$. The effect of ATP on $\left[{ }^{3} \mathrm{H}\right] \mathrm{PE}$ th formation in cultured cells with dexamethasone was greater than in control untreated cells. It is well known that $\mathrm{Ca}^{2+}$ has a role in the activation of PLD, since $\mathrm{Ca}^{2+}$ ionophores stimulate PLD (Exton, 1997). However, ionomycin did not stimulate PLD activity significantly in M-1 cells. Dexamethsonestimulated PLD activity was not further increased in presence of ionomycin and the activity was not changed by EGTA either (Figure 2 and data not shown). Taken together, these results suggest that $\mathrm{Ca}^{2+}$ does not appear to be responsible for PLD activation in M-1 cells. Vasopressin, bradykinin, and cAMP-increasing agent, dbcAMP were ineffective and simultaneous addition of these agents plus ATP or dexamethasone did not show any increase of PLD activity. The responses to dexamethasone and ATP were not augmented by PMA.

To distinguish between possible subtypes of PLD, we assessed the influence of ARF, $\mathrm{PIP}_{2}$ and oleate on PLD activity of the cells. Simple cell permeabilization was used to analyze whether PLD could be activated by guanine nucleotide and ARF in intact cells. Digitonin

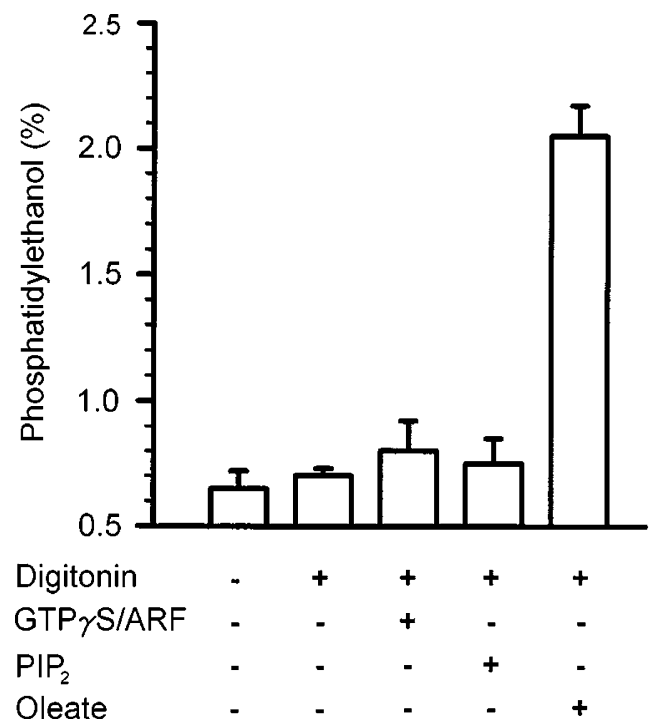

Figure 4. Effects of GTP $\gamma$ S and oleate on PLD activity in digitonin-treated $\mathrm{M}-1$ cells. $\mathrm{M}-1$ cells cultured in the medium without dexamethsone were labeled with $\left[{ }^{3} \mathrm{H}\right]$ myristic acid for $16 \mathrm{~h}$. Cells $\left(1 \times 10^{6}\right)$ were preincubated with $10 \mu \mathrm{M}$ digitonin for $10 \mathrm{~min}$ and stimulated with $100 \mu \mathrm{M}$ GTP $\gamma$ s plus $1 \mu \mathrm{M}$ ARF, $2 \mu \mathrm{g} \mathrm{PIP}$, or $1 \mathrm{mM}$ sodium oleate. PLD activity was measured as described in "Materials and Methods". Data represents mean \pm SD of three independent experiments. induces the formation of membrane pores enough to allow the passage of macromolecules, resulting in the depletion of cytoplasmic proteins. When the cells were permeabilized in the presence of guanine nucleotide, most of the GTP-binding proteins were also found to associate with membrane fraction. Figure 4 shows that there was a slight increase in $\left[{ }^{3} \mathrm{H}\right] \mathrm{PE}$ th formation when both GTPgS and ARF were present, but this difference was not statistically significant. In our experiments, simultaneous addition of recombinant RhoA with ARF did not affect PLD activity in M-1 cells. High basal PLD activity that has been observed in cells cultured in the presence of dexamethasone was not decreased in digitonin-treated cells and addition of dexamethasone in assay medium had no effect on activity either (data not shown). These results suggest that GTP-binding proteins such as ARF did not stimulate PLD in M-1 cells. It is reported that a second form of PLD, PLD2, is constitutively active in the presence of $\mathrm{PIP}_{2}$ (Colley et al., 1997b). However, PLD activity in digitonin-treated cells was not changed by addition of $\mathrm{PIP}_{2}$. In contrast, there was $215 \%$ greater $\left[{ }^{3} \mathrm{H}\right] \mathrm{PE}$ th formation in the presence of digitonin and oleate than digitonin alone. To provide additional support for the presence of oleate-dependent PLD in M-1 cells, we measured PLD activity with various concentrations of oleate. As shown in Figure 5, $\left[{ }^{3} \mathrm{H}\right] \mathrm{PE}$ th formation was increased with millimolar concentrations of sodium oleate in the absence of digitonin. This dosedependency coincides well with oleate-activated PLD in other intact cells or cell-free system (Massenburg et al., 1994; Okamura and Yamashita, 1994; Lee et al., 1998). Interestingly, oleate-induced $\left[{ }^{3} \mathrm{H}\right] \mathrm{PE}$ th formation in the

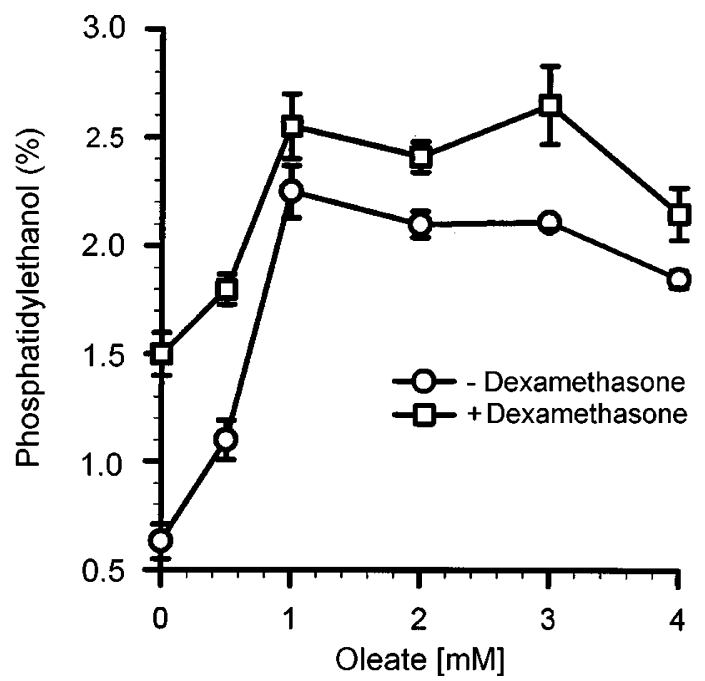

Figure 5. Dose-dependent effect of oleate on PLD activity in M-1 cells. M1 cells cultured in the absence or presence of $5 \mu \mathrm{M}$ dexamethasone were radiolabeled as in Figure 4 . The cells were incubated with indicated concentrations of sodium oleate for $15 \mathrm{~min}$ and measured formation of PEth. The data are represented as means \pm SD of three independent experiments. 


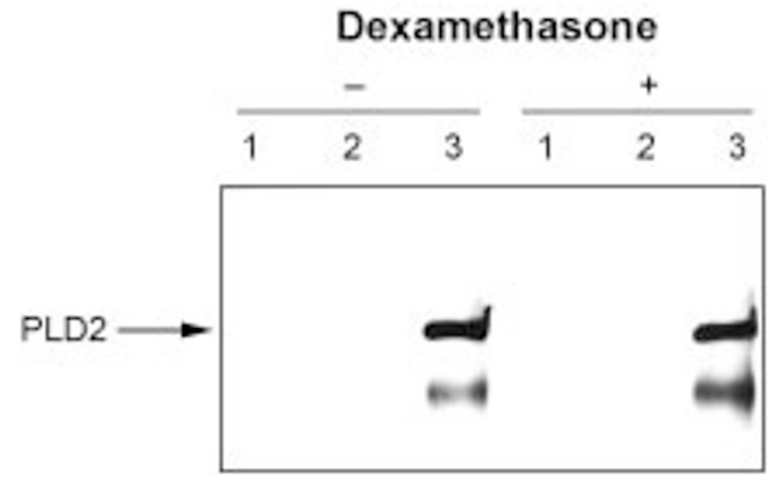

Figure 6. Expression level of PLD2 in M-1 cells. Confluent cells cultured in the absence $(-)$ or presence $(+)$ of dexamethasone were lysed in buffer containing $1 \%$ Triton $\mathrm{X}-100$ and $1 \%$ deoxycholate for $1 \mathrm{~h}$ at $4^{\circ} \mathrm{C}$. Equal amount of cell extracts $(10 \mathrm{mg})$ were immunoprecipitated with anti-PLD2 antibody and protein A agarose. The supernatant fraction (lane 2) and beads (lane 3) obtained by immunoprecipitation were analyzed by sodium dodecyl sulfate-polyacrylamide gel electrophoresis and western blot. Lane 1 shows cellular extracts $(100 \mu \mathrm{g})$.

cells was not affected by dexamethasone, suggesting that high basal activity in dexamethasone-treated cells may not be further activated by oleate. Taken together, these results demonstrate that enzyme responsible for the activity detected in $\mathrm{M}-1$ cells is oleate-dependent PLD and PLD2 rather than PLD1.

We next studied PLD expression at the protein level using peptide specific antibody against PLD1 and PLD2. Both PLD1 and PLD2 were not detected in extracts of M-1 cells by direct blotting. Western blot analysis of the immunoprecipitates with anti-PLD2 antibody revealed a single band of protein migrating with an apparent molecular weight of $100 \mathrm{kD}$ (Figure 6). When the expression of PLD2 in control and dexamethasone-treated cells was compared, the relative intensities of immunoreactive band were similar for both cells, indicating that dexamethasone had no apparent effect on PLD2 protein expression.

\section{Discussion}

Activation of PLD in mammalian cells is elicited by a wide variety of agonists in a variety of cell types. This report is the first to present evidence demonstrating PLD is stimulated by dexamethasone in the cortical collecting duct cell line, M-1. M-1 cells have been used as a model for studies of transport and signal transduction in the cortical collecting duct (Stoos et al., 1991; Nakhoul et al., 1998). Our initial experiments demonstrated an elevated basal PLD activity in M-1 cells cultured in the presence of dexamethasone compared to the untreated cells. [ ${ }^{3} \mathrm{H}$ ]myristic acid has been used successfully to radiolabel a phospholipid substrate pool that serves as a target for PLD. Treatment with the steroid did not affect the extent of phospholipid labeling relative to control cells. To further elucidate this effect, we have evaluated PLD activity by addition of dexamethasone to the assay medium containing cells. Dexamethasone significantly increased $\left[{ }^{3} \mathrm{H}\right] \mathrm{PE}$ th formation in both control and steroid treated cells and the change in activity after prolonged hormonal treatment coincides with that in short-term treatment, suggesting PLD activity is directly regulated by dexamethasone in intact cells. It has been also shown that dexamethasone significantly enhanced PLD activation by receptor agonists in retinoic aciddifferentiated HL-60 cells but inhibited PMA-stimulated PLD activity (Collado-Escobar and Mollinedo, 1994). Transepithelial resistance and $\mathrm{Na}^{+}$transport observed in cells cultured with dexamethasone was higher than in cells without dexamethasone (Nakhoul et al., 1998). Although it is possible to speculate that there is a correlation between the PLD activation and the increase of transepithelial resistance by dexamethasone, the role of PLD on transporter activity is unknown. It has been reported that stimulation of principal cells, in cortical collecting duct, by vasopressin induced fusion of intracellular vesicles with the apical membrane leading to increased water permeability (Fushimi et al., 1993; Nielsen et al., 1995). Although PA derived from PC might directly stimulate some proteins to bind to membranes, it also stimulates phosphatidylinositol 4-phosphate 5-kinase to produce $\mathrm{PIP}_{2}$ (Jenkins et al., 1994). $\mathrm{PIP}_{2}$ is reported to be an essential component in the process of membrane trafficking and the remodeling of cytoskeletal structure (De Camilli et al., 1996; Martin, 1998). Therefore, it is possible that changes in the phospholipid membrane composition are elicited by dexamethasone-stimulated PLD and these changes affect the activity of an ion channel or a closely related protein.

Collecting duct function is finely controlled by different hormones (Breyer and Ando, 1994). When we measured PLD activity in response to agents that modulate function of M-1 cells, we found that ATP stimulated $\left[{ }^{3} \mathrm{H}\right] \mathrm{PE}$ th formation. ATP exerts its effects via P2-purinoceptors which have been shown to be coupled to PLD activation in a number of cell types (Boarder et al., 1995). Treatment with dexamethasone or ATP showed a similar PLD activity pattern in both dexamethasonetreated and untreated cells. The activity was not changed by agents modulating intracellular $\mathrm{Ca}^{2+}$ concentrations. Dexamethasone has been reported to stimulate $\mathrm{Na}^{+}$transport, however increased intracellular $\mathrm{Ca}^{2+}$ elicited with thapsigargin did not alter transport in $\mathrm{M}-1$ cell (Nakhoul et al., 1998). We observed no additivity between the ATP and dexamethasone effects. It has been reported that vasopressin induces increased intracellular cAMP levels leading to activation of ion channels (Fushimi et al., 1993). However, vasopressin and other cAMP-increasing agents had no effect on formation of $\left[{ }^{3} \mathrm{H}\right] \mathrm{PE}$ th, suggesting that PLD is not involved in 
this process. Our results suggest that the response to steroid hormone and ATP is mediated through a PLD pathway in M-1 cells but the activation is independent of $\mathrm{Ca}^{2+}$.

The mechanism(s) by which the PLD activity increases in dexamethasone-treated cells is still unclear. In order to understand the role and characteristics of hormonesensitive PLD it is necessary to identify which isotype of PLD is present and activated in cells. PKC is one of the most potent stimulators of agonist-induced PLD activation, however we were unable to detect any activation of PLD by PMA at concentrations and incubation times shown to be maximal for other cells or tissues. The lack of PLD activity in response to PMA indicates that the PLD isotype in M-1 cell is not activated by PKC. There is evidence that PLD1 is the isoform regulated by PKC (Frohman et al., 1999), however Siddiqi et al. recently suggested that PLD2 might also be regulated by PKC in intact cells (Siddiqi et al., 2000). PLD1 activation is dependent on ARF and/or RhoA but PLD2 also can be activated by ARF in special circumstances (Frohman et al., 1999). Our results demonstrate that cell permeabilization with digitonin did not reduce basal PLD activity and addition of myristoylated recombinant ARF failed to reconstitute PLD activation, suggesting that PLD in M-1 cells is independent of small GTP-binding proteins. As shown in Figure 6 we were able to detect PLD2 (but not PLD1) in M-1 cells by immunoblot of immunoprecipitated proteins. Although it is not yet clear whether mRNA levels correspond well to protein levels, the mRNA for both PLD1 and PLD2 could be detected in kidney (Meier et al., 1999). It is possible that the expression of PLD1 is below the level of detection with the PLD1 antibodies used in our studies. It has been shown that regulation of cellular function by glucocorticoids involves protein synthesis. We have found that dexamethasone treatment did not affect significantly the expression of PLD and its regulatory factors such as ARF and RhoA in immunoblots. Although PLD2 expression appears to be unaltered by dexamethasone, PLD2 is likely to contribute to the high basal activity. Several different mechanisms might underlie the PLD2 stimulation such as covalent modification, cofactors or an increase in $\mathrm{PIP}_{2}$. However, we have not been able to detect any increase of activity by addition of $\mathrm{PIP}_{2}$. We can not rule out the possibility that $\mathrm{PIP}_{2}$ may not be required for the activation of PLD 2 in intact cells. In addition to PLD1 and PLD2 a novel PLD activated by fatty acid has been described (Okamura and Yamashita, 1994). Although the nature of this oleate-stimulated PLD has still not been resolved, it is not activated by GTP S, ARF, or $\mathrm{PIP}_{2}$. Lee et al. reported that oleate-dependent PLD in L1210 (lymphocytic mouse leukemia cells) is independent of PMA (Lee et al., 1998). Herein sodium oleate stimulated PLD activity similar to dexamethasone treatment, suggesting that oleate-dependent PLD plays a role in M-1 cells. However, PLD activity in dexamethasone-treated cells was not further increased by oleate. Recently, Ryu and his colleagues reported that PLA2mediated release of free fatty acid such as arachidonate and oleate stimulates PLD activity (Kim et al., 1999b). Therefore, we speculate that dexamethasone induces accumulation of free fatty acids leading to upregulate PLD activity but its activity is not further enhanced by exogenous addition of oleate. Although we can not rule out the increased expression of oleate-dependent PLD or regulators of PLD2, we demonstrated that dexamethasone can directly affect activation of PLD.

In conclusion, the present study revealed that PLD2 and oleate-dependent PLD are both present in M-1 cells and the PLD activity is increased by dexamethasone treatment. The PLD activity in M-1 cells is modulated by exogenous ATP and by oleate. Further studies are necessary to elucidate the function of PLD in the regulation of cortical collecting duct cells.

\section{Acknowledgement}

We thank Dr. Sung Ho Ryu and Dr. Pann-Gill Suh for kindly giving us the PLD1 antibody. This work was supported by Korea Research Foundation Grant 1998.

\section{References}

Boarder, M. R., Weisman, G. A., Turner, J. T. and Wilkinson, G. F. (1995) G protein-coupled P2 purinoceptors: from molecular biology to functional responses. Trends Pharmacol. Sci. 16: $133-139$

Bocckino, S. B., Blackmore, P. F., Wilson, P. B. and Exton, J. H. (1987) Phosphatidate accumulation in hormone-treated hepatocytes via a phospholipase D mechanism. J. Biol. Chem. 262: 15309-15315

Breyer, M. D. and Ando, Y. (1994) Hormonal signaling and regulation of salt and water transport in the collecting duct. Annu. Rev. Physiol. 56: 711-739

Brown, D. (1989) Membrane recycling and epithelial cell function. Am. J. Physiol. 256: F1-F12

Chalfant, M. L., Peterson-Yantorno, K., O'Brien, T. G. and Civan, M. M. (1996) Regulation of epithelial $\mathrm{Na}^{+}$channels from M-1 cortical collecting duct cells. Am. J. Physiol. 271: F861-F870

Chalifour, R and Kanfer, J. N. (1982) Fatty acid activation and temperature perturbation of rat brain microsomal phospholipase D. J. Neurochem. 39: 299-305

Collado-Escobar, D. and Mollinedo, F. (1994) Dexamethasone modifies the functional responses of the granulocytic differentiating HL-60 cells. Biochem. J. 299: 553-559

Colley, W. C., Altshuller, Y. M., Sue-Ling, C. K., Copeland, N. G., Gilbert, D. J., Jenkins, N. A., Branch, K. D., Tsirka, S. E., 
Bollag, R. J., Bollag, W. B. and Frohman, M. A. (1997a) Cloning and expression analysis of murine phospholipase D1. Biochem. J. 326: 745-753

Colley, W. C., Sung, T. C., Roll, R., Jenco, J., Hammond, S. M., Altshuller, Y., Bar-Sagi, D., Morris, A. J. and Frohman, M.A. (1997b) Phospholipase D2, a distinct phospholipase D isoform with novel regulatory properties that provokes cytoskeletal reorganization. Curr. Biol. 7: 191-201

Cross, M. J., Roberts, S., Ridley, A. J., Hodgkin, M. N., Stewart, A., Claesson-Welsh, L. and Wakelam, M. J. O. (1996) Stimulation of actin stress fibre formation mediated by activation of phospholipase D. Curr. Biol. 6: 588-597

De Camilli, P., Emr, S. D., McPherson, P. S. and Novick, P. (1996) Phosphoinositides as regulators in membrane traffic. Science 271: 1533-1539

Denker, B. M. and Nigam, S. K. (1998) Molecular structure and assembly of the tight junction. Am. J. Physiol. 274: F1-F9

Exton, J. H. (1997) Phospholipase D: enzymology, mechanisms of regulation, and function. Physiol. Rev. 77: 302-320

Exton, J. H. (1999) Regulation of phospholipase D. Biochim. Biophys. Acta 1439: 121-133

Frohman, M. A., Sung, T. C. and Morris, A. J. (1999) Mammalian phospholipase D structure and regulation. Biochim. Biophys. Acta 1439: 175-186

Fushimi, K., Uchida, S., Hara, Y., Hirata, Y., Marumo, F. and Sasaki, S. (1993) Cloning and expression of apical membrane water channel of rat kidney collecting tubule. Nature 361: 549552

Hammond, S. M., Altshuller, Y. M., Sung, T. C., Rudge, S. A., Rose, K., Engebrecht, J., Morris, A. J. and Frohman, M. A. (1995) Human ADP-ribosylation factor-activated phosphatidylcholine-specific Phospholipase $D$ defines a new and highly conserved gene family. J. Biol. Chem. 270: 29640-29643

Hammond, S. M., Jenco, J. M., Nakashima, S., Cadwallader, K., Gu, Q., Cook, S., Nozawa, Y., Prestwich, G. D., Frohman, M. A. and Morris, A. J. (1997) Characterization of two alternately spliced forms of phospholipase D1. Activation of the purified enzymes by phosphatidylinositol 4,5-bisphosphate, ADP-ribosylation factor, and Rho family monomeric GTPbinding proteins and protein kinase C-alpha. J. Biol. Chem. 272: $3860-3868$

Jenkins, G. H., Fisette, P. L. and Anderson, R. A. (1994) Type I phosphatidylinositol 4-phosphate 5-kinase isoforms are specifically stimulated by phosphatidic acid. J. Biol. Chem. 269: 11547-11554

Jones, D., Morgan, C. and Cockcroft, S. (1999) Phospholipase $D$ and membrane traffic. Potential roles in regulated exocytosis, membrane delivery and vesicle budding. Biochim. Biophys. Acta 1439: 229-244

Kang, J. H., Shin, I., Han, J. S. (1998) Changes of phospholipase D activity in TNF-alpha and anti-Fas/Apo1 monoclonal antibody induced apoptosis in HL-60 and A20 cells. Exp. Mol. Med. 30: 21-27
Kim, J. H., Kim, Y., Lee, S. D., Lopez, I., Arnold, R. S., Lambeth, J. D., Suh, P. G. and Ryu, S. H. (1999a) Selective activation of phospholipase D2 by unsaturated fatty acid. FEBS Lett. 454: 42-46

Kim, J. H., Lee, B. D., Kim, Y., Lee, S. D., Suh, P. G. and Ryu, S. H. (1999b) Cytosolic phospholipase A2-mediated regulation of phospholipase D2 in leukocyte cell lines. J. Immunol. 163: $5462-5470$

Ktistakis, N. T., Brown, H. A., Waters, M. G., Sternweis, P. C. and Roth, M. G. (1996) Evidence that phospholipase D mediates ADP ribosylation factor-dependent formation of Golgi coated vesicles. J. Cell. Biol. 134: 295-306

Lambeth, J. D., Kwak, J. Y., Bowman, E. P., Perry, D., Uhlinger, D. J. and Lopez, I. (1995) ADP-ribosylation factor functions synergistically with a $50-\mathrm{kDa}$ cytosolic factor in cellfree activation of human neutrophil phospholipase D. J. Biol. Chem. 270: 2431-2434

Lee, S. Y., Yeo, E. J. and Choi, M. U. (1998) Phospholipase D activity in L1210 cells: a model for oleate-activated phospholipase D in intact mammalian cells. Biochem. Biophys. Res. Commun. 244: 825-831

Lee, T. G., Park, J. B., Lee, S. D., Hong, S., Kim, J. H., Kim, Y., Yi, K. S., Bae, S., Hannun, Y. A., Obeid, L. M., Suh, P. G. and Ryu, S. H. (1997) Phorbol myristate acetate-dependent association of protein kinase $\mathrm{C}$ alpha with phospholipase D1 in intact cells. Biochim. Biophys. Acta 1347: 199-204

Lopez, I., Arnold, R. S. and Lambeth, J. D. (1998) Cloning and initial characterization of a human phospholipase D2 (hPLD2). ADP-ribosylation factor regulates hPLD2. J. Biol. Chem. 273: 12846-12852

Martin, T. F. (1998) Phosphoinositide lipids as signaling molecules: common themes for signal transduction, cytoskeletal regulation, and membrane trafficking. Annu. Rev. Cell Dev. Biol. 14: 231-264

Massenburg, D., Han, J. S., Liyanage, M., Patton, W. A., Rhee, S. G., Moss, J. and Vaughan, M. (1994) Activation of rat brain phospholipase $\mathrm{D}$ by ADP-ribosylation factors 1,5 , and 6 : separation of ADP-ribosylation factor-dependent and oleatedependent enzymes. Proc. Natl. Acad. Sci. USA 91: 1171811722

Meier, K. E., Gibbs, T. C., Knoepp, S. M. and Ella, K. M. (1999) Expression of phospholipase D isoforms in mammalian cells. Biochim. Biophys. Acta 1439: 199-213

Nakhoul, N. L., Hering-Smith, K. S., Gambala, C. T. and Hamm, L. L. (1998) Regulation of sodium transport in M-1 cells. Am. J. Physiol. 275: F998-F1007

Nielsen, S., Marples, D., Birn, H., Mohtashami, M., Dalby, N. O., Trimble, M. and Knepper, M. (1995) Expression of VAMP2-like protein in kidney collecting duct intracellular vesicles. Colocalization with Aquaporin-2 water channels. J. Clin. Invest. 96: $1834-1844$

Okamura, S. and Yamashita, S. (1994) Purification and characterization of phosphatidylcholine phospholipase $D$ from pig lung. J. Biol. Chem. 269: 31207-31213 
Park, B. J., Kim, J. H., Han, J. S. and Jung, P. M. (1999) Effects of ceramide on apoptosis and phospholipase $D$ activity in FRTL-5 thyroid cells. Exp. Mol. Med. 31: 142-150

Roth, M. G. (1999) Lipid regulators of membrane traffic through the Golgi complex. Trends Cell Biol. 9: 174-179

Siddiqi, A. R., Srajer, G. E. and Leslie, C. C. (2000) Regula- tion of human PLD1 and PLD2 by calcium and protein kinase C. Biochim. Biophys. Acta 1497: 103-114

Stoos, B. A., Naray-Fejes-Toth, A., Carretero, O. A., Ito, S. and Fejes-Toth, G. (1991) Characterization of a mouse cortical collecting duct cell line. Kidney Intl. 39: 1168-1175 